\title{
Between Revenues and Public Service Delivery so $\mathrm{s}$ and PSA $s$ in Indonesia
}

\author{
Shidarta \\ Bina Nusantara University, Jakarta, Indonesia \\ shidarta@binus.edu \\ Stijn Cornelis van Huis \\ Bina Nusantara University, Jakarta, Indonesia \\ stijnvanhuis@binus.edu
}

\begin{abstract}
This article examines the development of policies regarding the state-owned enterprises (SOE s) and public service agencies (PSAs) in Indonesia. In 2004, the government of Indonesia introduced PSAs - government agencies that were given large autonomy to manage their financial affairs. The rationale behind this autonomy is consistent with the New Public Management ideal: the creation of more market-oriented government institutions with the objective of increasing the efficiency and effectiveness of public service delivery. The PSA policy has increased state revenues significantly, yet the quality of services and accountability has not improved accordingly. A comparison with soEs reveals that the restructuring of government agencies and soe s took place before a supportive framework was set in place. We argue that to tackle informality and to safeguard the social functions of public services, the spearheads of efficiency and revenues in Indonesian bureaucratic reform policies require a strong foundation, consisting of regulatory and ideological components.
\end{abstract}

\section{Keywords}

state-owned enterprises (soE s) - public service agencies - restructuring - economic policy - Indonesia 
In his first speech after being re-elected, Indonesian president Joko Widodo, popularly known as Jokowi, stressed the importance of having a mindset change within the bureaucracy. He was quoted as saying:

Bapak, Ibu, brother and sister compatriots. All the people of Indonesia whom I love. Ladies and gentlemen, we all have to be aware that now we live in a very dynamic global environment. We know the characteristics of this global phenomenon: full of change, full of velocity, full of risk, full of complexity and full of surprises that are far from what we expected.

Therefore, we have to find a new model, new method and new values when looking for solutions to every problem with innovation and we all have to be willing [to change] and we will force [people] to be willing [to change]. We have to abandon old methods, old patterns, both in managing institutions and in managing government. What is no longer effective, we will make effective. What is no longer efficient, we will make efficient! ${ }^{1}$

Efficiency, bureaucratic reform, and a change of mindset are essential ingredients in Jokowi's administration's recipe for economic success. New Public Management ideals are seen as the key to Indonesia's development, ${ }^{2}$ as government agencies must become business- and investor-friendly. The Grand Design Reformasi Birokrasi 2010-2015 (the Grand Design for Bureaucracy Reform 20102025), a programme launched by President Susilo Bambang Yudhoyono in 2010, ${ }^{3}$ has been taken up with more vigour under President Joko Widodo's administration (Jokowi, 2015-present). Badan Layanan Umum (BLU, Public Service Agencies; hereafter PSAs), government agencies that possess considerable freedom to manage their own economic affairs, fit well in this New Public Management ideology. The first 13 national PSAs were established in 2005

1 Karina M. Tehusijarana, "We can be one of strongest countries in world": Jokowi's full speech', The Jakarta Post, 15-7-2019. https://www.thejakartapost.com/news/2019/o7/15/we-can-be -one-of-strongest-countries-in-world-jokowis-full-speech.html (accessed 15-8-2019).

2 Bambang Bamsoet, the Speaker of Indonesia's parliament, stated that bureaucracy reforms are inspired by 'New Public Management' (English in original). Mikhael Gewati, 'Agar efektif dan efisien, DPR dukung reformasi total birokrasi', Kompas.com, 23-7-2019. https://kilasparle men.kompas.com/dpr/read/2019/o7/23/182148o1/agar-efektif-dan-efisien-dpr-dukung-refor masi-total-birokrasi (accessed 15-8-2019).

3 Through Presidential Regulation No. 81 Year 2010. 
under the President Megawati's administration. This number has grown to 222 PSAs today (2019).

This article examines the development of these PSAs in Indonesia, in particular how it relates to restructuring policies pertaining to Badan Usaha Milik Negara (BUMN, state-owned enterprises; hereafter soEs). Restructuring of soes has led to different levels of hybridization, which denotes a process in which SoE s' management adopts private sector management styles and blends public sector and private sector characteristics (Kikeri and Nellis 2002). The world-wide adoption of private sector management styles by soE $s$ in the $198 \mathrm{os}$ was part of the same New Public Management ideology that inspires Indonesian bureaucratic reforms today.

The main argument against state control of SOE s, apart from the libertarian ideological point that state interference in the economy should be kept as low as possible (Potrafke 2010), is their alleged inefficiency (Musacchio and FloresMacias 2009). This persistent idea of inefficiency of soE s, however, is increasingly being contested by research that moves away from the state-owned and privately owned dichotomy and takes into account the many different types of hybrid SOEs. SOE s differ in the proportions of soes' private ownership, public service function, the ascribed strategic function, and level of competition with domestic and global players (Bruton et al. 2015). Many hybrid soe s perform economically very well-sometimes better than privately owned companies (Inoue, Lazzarini, and Musacchio 2013; Goldeng, Grunfeld, and Benito 2008). ${ }^{4}$ Under the Jokowi presidency, this positive assessment of soE s facilitated a new developmentalism in which soe s play an important role (Warburton 2016).

Although soes do not dominate Indonesia's economy, soEs are among the largest Indonesian companies. To illustrate this: in $2013,69 \%$ of the volume of the Indonesian companies in the Forbes Global 2000-the world's 2,000 largest companies according to Forbes-were soes (Kowalski et al. 2013). In recent Indonesian history, and especially during times of economic crises, the government of Indonesia introduced models for reforms aimed at tackling the informality, nepotism, and corruption that mar soes (Ilmar 2012; Moeljono 2004; Diah 2003).

The establishment of PSAs in Indonesia was inspired by the ideas of New Public Management, an ideology that sees the private sector as model for public

4 Research in Norway has found that soes in Norway perform better than privately owned enterprises in sectors with strong market competition, whereas research in Brazil demonstrates that minority government ownership has positive effects on an enterprise's performance. See Goldeng, Grunfeld, and Benito 2008; Inoue, Lazzarini, and Musacchio 2013. 
sector management. New Public Management, modelled to 198os' public sector reforms in the Organisation for Economic Cooperation and Development (OECD) countries, is characterized by several shifts in management policies ranging 'from policy making to management skills, from a stress on process to a stress on output, from orderly hierarchies to an intendedly more competitive basis for providing public services, from fared to variable pay, and from a uniform and inclusive public service to a variant structure with more emphasis on contract provision' (Hood 1995:95). New Public Management was also at the heart of the worldwide managerial reforms of soE s (Larbi 1999), including in Indonesia (Moeljono 2004; Diah 2003), which means that explorative parallels between PSAs and SOE s can be drawn.

Despite the global appeal of New Public Management reforms, there is no conclusive evidence that application of a more corporate style of public management will lead to a better performance of public services in the long run. International reviews of literature on privatization of government services show that results in terms of cost-saving are mixed (Bel and Warner 2008; Boyne 1998) and consequences for consumers in terms of prices and efficiency and quality of service delivery are inconclusive and most often not included in assessments at all (Petersen, Helby, and Vrangbaek 2018). For instance, in the United States and Europe, partial contracting out to private-health-service delivery firms did not increase cost-effectiveness and efficiency of the health services delivered (Bel and Esteve 2019).

PSAs are established to create a more private-sector-like, corporate governance within government agencies. In developing countries, one of the main obstacles to reach this management type is the informality of the bureaucratic culture (Schick 1998). This article demonstrates how in Indonesia structural changes pertaining to PSAS and SOEs have been implemented without creating sufficient checks and controls to tackle informality of the bureaucratic culture. The case of soes shows how, following restructuring and corporatization policies in the 1980s, high bureaucrats in sectoral ministries and SOE management continued to use soEs as a 'cash-cow' (Moeljono 2004:8-9). The SOE case shows that without changing informality within SOE management, restructuring will not reduce the risks of collusion and corruption.

This article argues that the history of soE reforms demonstrates that policies regarding PSA s should not be measured only through cost-efficiency and state revenues. Instead, accountability must be prioritized and include both financial reporting and reporting of the quality and accessibility of social and public service delivery. Such accountability must have an ideological foundation that underlines social functions of soEs and counters informality. 
soEs are created to run economic sectors on behalf of the state. Arguments for creating soes are concerns about national security, insufficient investment from the private sector in certain business areas, as well as redistribution of certain services so that they are accessible for citizens all over the country. In many cases, soes with a public utility function (railways, postal services, telecommunication, electricity) have (or had in the past) a natural monopoly, which denotes a situation in which the government develops a monopoly for soE $\mathrm{s}$ in market segments where conditions are not profitable for private competitors to invest (Heath and Norman 2004; Lewin 1982).

The Indonesian 1945 Constitution heavily mandates the state to steer the country's economic development. The main architect of the economic provisions in Indonesia's 1945 Constitution was Mohammad Hatta, the first vicepresident of the Republic of Indonesia (Kusuma 2009). Article 33 of the 1945 Constitution delineates the role of the Indonesian government in economic affairs. The original Article 33 consists of only three paragraphs and reads as follows:

1. The economy is to be organized as a common effort based on the family principle;

2. Those sectors of production that are strategic to the country and those that affect public necessities are under the powers of the State;

3. The land, the waters and the natural resources contained in it are under the powers of the State and shall be used to the greatest welfare of the people.

The 1945 Constitution does not stipulate full state control over its economyit is not a socialist model. However, it does require state control over natural resources and over economic areas that are deemed strategic or affect the ability of people to meet their basic needs. The state's management of essential economic sectors must offer the greatest benefit for the people, a provision that resembles European social-democratic ideologies. In the words of Muhammad Hatta:

Whereas the free market [ideology] does not want governments to interfere in the economy through regulations, our idea of a government-led economy (ekonomi terpimpin) has the opposite objective: the government must actively regulate the economy so that social justice can be achieved. If we let the economy be run by free-market forces, this means that we allow the strong to prey on the weak.

HATTA 1979 [1959]: 7 
Hatta's supportive words for state regulation and 'welfare economics' (Hatta 1979: 29), do not clarify what exactly economic control by the state entails. It is clear, however, that Hatta had no preference for an soe s-dominated economy, but for an economy that is run by private enterprises 'run in the family spirit', such as cooperatives (Hatta 1979:35, 36). Hatta's ideas of a nationalist economy still have a strong following today.

The more than two decades of Sukarno's so-called Orde Lama (Old Order) regime (1945-1967) can be divided into two time periods. In the first period of pragmatism (1945-1957), Indonesia took a pragmatic approach towards foreign investors, a group that was dominated by the Dutch. As the former colonizers, the Dutch still held a large stake in the Indonesian economy. The second period (1958-1965) is characterized by nationalization of Dutch companies and economic nationalism (Lindblad 2011).

Upon the transfer of sovereignty by the Dutch in 1949, which followed the Declaration of Independence in 1945 and four years of independence struggle, Indonesia took over several soE s established by the colonial administration of the Netherlands Indies, including the post office, the state railways, and various mining and plantation interests. Other enterprises were set up by the government, including Bank Negara Indonesia (BNI, State Bank of Indonesia), the Central Trading Company, and the Usaha Industri Indonesia (Usindo, Indonesian Industries), in order to compete with Dutch banks and trading companies. Private banks, railways, utilities, and estates were nationalized, based on mutual agreement; compensation was paid based on actual worth.

Indonesia did not only indebt itself through nationalizations; it also took on over $\$ 1.1$ billion of public debt, more than any ex-colony in Asia (Dick et al. 2002:71). This meant that the newly founded republic started its independence with a large burden of repayments to the Netherlands and little room for investments in its own economy.

Nonetheless, Indonesia achieved a moderate positive economic growth in the 1950s, as the country was able to take advantage of a boom in the world economy. Foreign enterprises, but also Indonesian smallholders, played an important role in the economic recovery after World War II (Lindblad 2010).

Relations with the Netherlands, as the former colonizer, remained strained for the following reasons. First, in $195^{1}$ Indonesia changed its federal state model — preferred by the Netherlands - into a unitary state model. Second, Dutch companies were slow in implementing the promised Indonesianisasi 
(Indonesianization) of personnel and management (Lindblad 2011). Third, Indonesia and the Netherlands were in conflict over the fate of West Papua. West Papua was part of the Netherlands Indies but remained in Dutch hands after the Dutch sovereignty transfer in $1949 .{ }^{5}$

In 1958 Indonesia terminated diplomatic relations with the Netherlands and pursued a policy of confrontation towards its ex-colonial power. The situation ignited nationalistic and anti-Dutch sentiments and resulted in the nationalization of hundreds of Dutch private companies that operated in a variety of business areas, such as mining, plantations, transportation, postal services, and pawnshops. Management of these soes sas often handed over to the military (Dick et al. 2002:187). In 1959 Sukarno's administration abolished parliament and concentrated the powers in the hands of the president, which marked the so-called Demokrasi Terpimpin (Guided Democracy). The Guided Democracy had an economic component, the 'Guided Economy'. In the eyes of Sukarno, Indonesia's economy should be subject to strict political control.

In 196o Sukarno issued a government regulation in lieu of law pertaining to soE s, with reference to Article 33 of the Constitution and as the 'structure for a guided economy towards the implementation of Indonesian socialism. ${ }^{6}$ In this regulation, an $\operatorname{SOE}$ (state-owned enterprise or perusahaan negara) is defined as a production unit that has three functions: to provide public services, to generate public revenues, and to generate income. soes should pursue these three goals at once. The Penjelasan Umum (Explanatory Memorandum) to the regulation mentions that SOE s have to be self-sustainable and are not allowed to become a burden to the state budget.

soEs were seen as an instrument for social and economic development, as set forward in state economic-development plans. These plans were financed through state banks. ${ }^{7}$ Nine state-owned trading houses were made responsible for import of essential goods (about $70 \%$ of the total trade) and the bulk of

5 In the end, a referendum was organized in which West Papua voted to become part of the Republic of Indonesia. While the way the referendum was organized is not without controversy, the outcome was internationally accepted. See Saltford 2003 .

6 See Pasal 4 ayat (1) Peraturan Pemerintah Pengganti Undang-Undang No. 19 Tahun 196o tentang Perusahaan Negara (Article 4 paragraph (1) of the Government Regulation in Lieu of Law No. 19 of 196o on State-Owned Enterprises). Later that year, the status of this government regulation was changed into Law (Undang-Undang No. 19 Tahun 196o tentang Perusahaan Negara).

7 Sukarno considered the role of soe s in Yugoslavia's economy as a very successful example of a socialist compromise model between capitalism and communism. See Lubis and Buxbaum 1986. 
exports. The envisioned role of soEs in developing the economy did not mean that the entire economy should be run by the state. While international trade was nationalized, domestic commerce remained largely in private hands (Lindblad 2006; Dick et al. 2002:187).

At this stage, the envisioned state-led development under the guidance of soes was not realized. In the early 196os, the performance of the economy rapidly worsened. The problems experienced were lack of credit, lack of foreign investment, and bad management. The Indonesian government lacked resources and tax income, while the nationalization campaign, aggressive foreign policy towards Malaysia (1963-1966), withdrawal from the United Nations (1965), and general prevalence of socialist and nationalist political discourses against 'imperialists' forces made Western foreign companies hesitant to invest in the economy. Management of soes, which for a large part had been handed over to the Indonesian military, ended in failure due to a lack of managing skills and experience (Sungkar 2008:98). As a result of national and international economic developments, the republic entered its twenty-yearold anniversary with a hyperinflation rate of $175 \%$ and a crumbling economy (Hossain 2005:50).

In 1965, in a complex political and economic context, a coup attempted by communist elements of the military took place. The Indonesian military, under the supervision of General Soeharto, were quick to act and headed a crackdown of the Partai Komunis Indonesia (Indonesian Communist Party), which led to many casualties and the incarceration of many of its members and sympathizers. In 1966 Sukarno was pressured to sign the Surat Perintah 11 Maret (Supersemar, 11 March Executive Order), which transferred many of his presidential powers to General Soeharto. On 27 March 1968, General Soeharto ascended to the presidency.

The economic policies of the New Order (1968-1998) can be divided into three phases, which coincide with restructuring policies regarding soes. The first phase (1967-1973) is characterized by stabilization, rehabilitation, partial liberalization, and economic recovery; the second phase (1974-1982), by oil booms, rapid economic growth, and increasing government intervention; and the third phase (1983-1996), by a post-oil boom, deregulation, renewed liberalization, and rapid, export-led growth (Dick et al. 2002:206).

In the first phase of the New Order (1968-1973), the goal of economic stabilization was primary as Indonesia sought to attract domestic and foreign 
investment. A switch in Indonesia's economic and political orientation in fact had already taken place in 1967, the lastyear of Sukarno's presidency, when General Soeharto was effectively in control. Undang-Undang No. 1 Tahun 1967 tentang Penanaman Modal Asing (Law No. 1 of 1967 on Foreign Investment; hereafter the ${ }_{1967}$ Foreign Investment Law) opened up the economy to foreign investment by offering tax benefits and free transfers of profits to those companies willing to invest in Indonesia's economy. The explanatory memorandum to the law describes the reliance of the economy on foreign capital as a temporary necessity and a prerequisite to develop the country's national economy, human resources, and know-how. In 1968, Undang-Undang Penanaman Modal Dalam Negeri (the 1968 Domestic Investment Law) offered similar incentives and guarantees to Indonesian entrepreneurs.

The 1967 Foreign Investment Law did not open up the entire economy as it restricted the access for foreign companies in a number of sectors that were deemed strategic by the New Order government. Areas that remained fully the domain of soes were harbours, electricity supplies, ferries, domestic flights, drinking water supply, public train services, atomic energy development, and mass media. In all these areas, with the exception of the mass media, only soe $\mathrm{s}$ were allowed to operate (Robison 1988).

The more liberal economic orientation went hand in hand with the first restructuring phase of soes, stipulated by the Peraturan Pemerintah Pengganti Undang-Undang No. 1 Year 1969 on Bentuk-Bentuk Usaha Negara (Government Regulation in Lieu of Law on the Types of State-Owned Enterprise; hereafter the 1969 soe s Law). ${ }^{8}$ During Sukarno's presidency, one type of soe existed: the perusahaan negara (state enterprise). In 1969 the New Order introduced three types of soes (see Table 1): the perusahaan jawatan (public service company), the perusahaan umum (public utility company), and the perusahaan persero (limited liability company).

The three types of soes introduced during the New Order are still based on the three functions of the perusahaan negara in the old 196o soes Law. However, SOE s do not have to fulfil the three functions at once. The 1969 soe $s$ Law defined soes as state enterprises with the function of providing public services, creating public benefit, or generating income. Limited liability companies were allowed to issue shares on the stock market. What all soes had in

8 According to the Penjelasan Umum (Explanatory Memorandum) of the Government Regulation in Lieu of Law No. 9 Year 1969 (later that year its status was changed into undang-undang, or law), these reforms were necessary as the 1960 government regulation in lieu of Law on soEs and its socialist rationale had resulted in inefficiently run soE $\mathrm{s}$. Therefore, the management of soE s should be de-bureaucratized and de-concentrated. 
TABLE 1 Types of sOE s in Indonesia since 1969

\begin{tabular}{|c|c|c|c|c|}
\hline & & $\begin{array}{l}\text { Public service } \\
\text { company }\end{array}$ & $\begin{array}{l}\text { Public utility } \\
\text { company }\end{array}$ & $\begin{array}{l}\text { Limited liability } \\
\text { company }\end{array}$ \\
\hline 1. & Function & Public service & Public utilities & $\begin{array}{l}\text { To make profit and encourage } \\
\text { the operation of private sector } \\
\text { companies/cooperatives }\end{array}$ \\
\hline 2. & Business model & Non-profit & Self-sustaining & Fully profit-oriented \\
\hline \multirow{2}{*}{\multicolumn{2}{|c|}{ 3. Capital }} & $\begin{array}{l}\text { State budget under } \\
\text { a certain ministry }\end{array}$ & $\begin{array}{l}\text { Separate capital } \\
\text { from state budget }\end{array}$ & $\begin{array}{l}\text { Separate capital from state } \\
\text { budget }\end{array}$ \\
\hline & & No private capital & No private capital & $\begin{array}{l}\text { Private investors can be } \\
\text { minority shareholders }\end{array}$ \\
\hline & Legal status & Public legal entity & Public legal entity & Private legal entity \\
\hline
\end{tabular}

common during this time was that their management fell under the responsibility of the relevant sectoral ministry. Thus, despite the financial autonomy they had on paper, their daily management, including financial matters, continued to be subject to strong government control. During this era, soes continued to dominate the 'strategic' segments of the economy (Booth and McCawley 1981:64).

The continuation of nationalist economic policies became more visible during the second phase of the New Order. The boom in oil prices in the 1970s increased state revenues and made the New Order government less dependent on private investments. This led to increased state intervention in the economy. Tax revenues from foreign oil companies operating in Indonesia rose from about one third of total government revenues before 1974 to more than two thirds by 1979. Government's expenditure rose from $9.3 \%$ to $22.1 \%$ respectively (Dick et al. 2002:208). Higher state revenues combined with nationalist sentiments in society, such as those expressed during the 1974 Malari riots against the growing Japanese business influence, led to the introduction of restrictive measures on foreign investment and preferential treatment of indigenous firms and businessmen. From 1974 new foreign direct investment could enter Indonesia only in the form of joint ventures with Indonesian companies (Robison 1988).

The third phase of New Order economic policies started with an economic crisis. In the early $1980 \mathrm{os}$, the price of oil fell dramatically. A loss of $14 \%$ of the government's annual budget meant that cuts in the state budget were necessary, including cuts pertaining to SOE s (Diah 2003:188). Foreign invest- 
ment was partly deregulated again and a number of restrictions in the exportoriented segments of the market were removed. This resulted in a large disparity between economic policies on micro- and macroeconomic levels, as the domestic market remained highly regulated, restricted, and characterized by subsidies and preferential treatment for Indonesian companies (Dick et al. 2002:214; see also Rock 2003).

Less government funding revealed that the performance of many soes was weak. The government attempted to increase the financial accountability of soes by stipulating dual supervision by the Kementerian Keuangan (Menkeu, Ministry of Finance; hereafter MoF) and the relevant sectoral ministry. ${ }^{9}$ soe $\mathrm{s}$ were also made subject to a rightsizing policy. Rightsizing is defined by the BusinessDictionary as ' $[t]$ he process of a corporation reorganizing or restructuring their business by cost-cutting, reduction of workforce, or reorganizing upper-level management.' ${ }^{10}$ The dual supervision and rightsizing policies, however, did not lead to professionalism and accountability within soes (Diah 2003:187). On the contrary, sOE s continued to be a source of collusion between the central government, the military, and local bureaucracies (Rock 2003; Robison 1988; Liddle 1985).

The fact that the New Order reduced the number of soes from 822 in 1967 to 200 in 1989 (Diah 2003:187) is not indicative of less support for soe s under the New Order. While the role of soE s in the New Order's economy was limitedsoe s produced approximately $15 \%$ of GDP in 1991—SOE s' symbolism as carriers of a nationalist economy remained strong (Sungkar 2008:98). Even during the economic crisis of 1997 President Soeharto remained strongly opposed to privatization of soEs (Moeljono 2004:14). Several large SOE s were allowed to dominate strategic sectors of the economy. These included Pertamina (an oil company), Garuda (the state airline), state commercial banks, and telecommunications companies.

Meanwhile, Indonesia's measures to tackle the economic crisis appeared successful. As an exporter of labour-intensive manufactured products, Indonesia was no longer dependent on oil prices. Oil palm also became an important export product to Indonesia. From 1988 to 1996, economic growth in Indonesia was high, between $7.3 \%$ and $9 \%$ annually. By the 199os, Indonesia was coined

Peraturan Pemerintah No. 3 Year 1983 tentang Tata Cara Pembinaan dan Pengawasan Perusahaan Jawatan, Perusahaan Umum, dan Perusahaan Perseroan (Government Regulation No. 3 of 1983 on Fostering and Supervision Mechanisms for Public Service Companies, Public Utility Companies, and Limited Liability Companies). www.businessdictionary.com/definition/rightsizing.html (accessed 18-10-2018). 
as one of the Southeast Asian Tigers, which illustrates how the struggling economy of the 196os had been turned into one of the economic successes within the developing world.

In 1990, this time in in the context of economic success, the Indonesian government sought private investments for soE s. It issued the Peraturan Pemerintah No. 55 Tahun 1990 tentang Perusahaan Perseroan (Persero) yang Menjual Sahamnya kepada Masyarakat melalui Pasar Modal (Government Regulation No. 55 of 1990 on Limited Liability Companies that Sell Shares to the Public through the Stock Market; hereafter Government Regulation 55/199o) with the stated purpose of increasing the autonomy of soes to manage their own financial affairs. Under the 'go public' policy, profitable soe s were encouraged to look for private investors and to become hybrid soE s: limited liability companies that operate in a competitive market and are partly in private hands. The government developed a strong preference for the limited liability company, a hybrid SOE with a profit maximalization rationale. As we will see, after President Soeharto stepped down, this preference for limited liability companies would be enshrined in law.

\section{$5 \quad$ Further Liberalization during the Reformasi (1998-2004)}

The fall of Soeharto's New Order regime in 1998 was triggered by the 1997 Asian crisis. The way that the Asian crisis hit Indonesia took most economists by surprise, as in 1996 Indonesia still recorded an economic growth of $7.8 \%$. Within two years' time, Indonesia's GDP decreased with more than $15 \%$. The fall of the rupiah, from IDR 2,400 per Us dollar to IDR 17,000, tripled Indonesia's foreign debt (Sjöholm 1999). In 1997 President Soeharto reluctantly signed a us \$ 43 billion loan agreement with the IMF. The crisis was detrimental for Soeharto's reputation as the Bapak Pembangunan (Father of Development), the architect of Indonesia's economic success. The economic crisis and the social and political unrest made Soeharto's position untenable. On 21 May 1998, President Soeharto resigned.

The first years of the Reformasi, the time period of political and economic reforms following Soeharto's resignation (1998-2004), saw economic reforms and decentralization of the government. On 19 October 1998, the Government of Indonesia's signed a Letter of Intent for economic reforms, as part of its loan agreement with the IMF. Just as in the early 1980s, a dramatic decrease of the state budget forced the government to look into the role of soes in Indonesia's economy. In 1998, with the aim to increase its grip on soEs, the government decided to transfer the ineffective dual supervision of soes to a 
new Kementerian Badan Usaha Milik Negara (Ministry of State-Owned Entreprises; hereafter Ministry of soEs). ${ }^{11}$ Within 18 months, the ministry restructured state banks and closed 16 of them, liberalized the agricultural sector, and restructured the state airline and the state electricity company. The Ministry of sOE s sold shares in five out of 12 companies intended to be privatized (Sungkar 2008:101).

In 2002, Article 33 of the Constitution was amended. The amended Article 33 still stipulates a state-controlled national economy for the welfare of the people, yet with the addition that the state is expected to balance several economic and social development goals. Hence Article 33 kept providing supporters of nationalist economic policies with constitutional legitimacy. For example, the prominent nationalist economist Sri Edhi Swasono argued that Indonesia's economic reforms during the Reformasi were contrary to Article 33 of the Constitution. ${ }^{12}$

During the Reformasi the Indonesian government was under pressure to reform its domestic economy; hence, restructured soE s. Restructuring of SOE $s$ sometimes had adverse social consequences. For example, in 2003 the World Bank warned that generation shortfalls were "[one of the] most critical issues facing [the country]'. Indonesia had requested funding to improve its electric generation branch. The World Bank insisted that Indonesia had to restructure the Indonesian electricity company's urban operations and privatize the generation companies first and provided funding for such restructuring. A long period of electricity outages in Indonesia's cities was taken for granted (Engel 2006).

Similarly, the World Bank pushed an agenda for the privatization of water utilities in Indonesia. At the end of the Reformasi period the government passed Undang-Undang No. 7 Tahun 2004 tentang Sumber Daya Air (Law No. 7 Year 2004 on Water Resources; hereafter the 2004 Water Resources Law), creating anxiety among farmers about their future access to water irrigation..$^{13} \mathrm{~A}$

11 Through the Peraturan Pemerintah No. 5o Tahun 1998 tentang Pengalihan Kedudukan, Tugas dan Kewenangan Menteri Keuangan Selaku Pemegang Saham atau Rapat Umum Pemegang Saham pada Perusahaan Perseroan kepada Menteri Negara Pendayagunaan Badan Usaha Milik Negara (Government Regulation No. $5^{\circ}$ of 1998 on Transfer of Position, Duties and Authority of the Minister of Finance as the Shareholder or the General Meeting of Shareholders at Limilited Liability Companies to the Minister of Sate-Owned Enterprises).

12 'Penjualan saham вUмN awal asing berkuasa', Kompas.com, 29-04-2010. https://money .kompas.com/read/2010/o4/29/1332366o/penjualan.saham.bumn.awal.asing.berkuasa (accessed 24-10-2019).

13 'PK UU Sumber Daya Air No. 7/2004 diajukan ke MK', Media Indonesia, 29-7-2004. 
group of farmers, supported by the Indonesian NGO Walhi, took class action and filed a case with the Makhamah Konstitusi (Constitutional Court) for constitutional review. Walhi lost the case, as the future adverse effects of the law could not yet be proven. In 2015, in a case filed by the Muslim organization Muhammadiyah, the Constitutional Court ruled the 2004 Water Resources Law unconstitutional. ${ }^{14}$

Fear for privatization of basic public utilities such as electricity and water facilitated nationalist resistance against the privatization of all types of soEs (Nugraha 2004). Indeed, the political situation in Indonesia, where the military and politicians have a large stake in SOE s, makes privatization of soEs a very delicate political matter. Managerial reforms of soes are difficult to achieve, let alone privatizations.

\section{$6 \quad$ Restructuring of SoE $s$ after 1998}

As said, in 1998, under the transitional government of President Habibie (19981999), the Ministry of soes was created. It took over the supervision of soes from 17 sectoral ministries. Tanri Abeng, who had been the main advisor of the former president Soeharto concerning SOEs, became the first minister of soEs. A blueprint for soe reform was developed, with the ultimate objective of transforming SOE s into professional super holdings operating in ten sectors: telecommunications and media; construction; energy; tourism; logistics; strategic industries; mining; forestry, paper, and publishing; the agro-industry and agro-processing sector; and financial services (Moeljono 2004:16). A restructuring scheme was developed, which would become the model of future soErestructuring policies (see Figure 1).

The government under President Abdurrahman Wahid (1999-2001) formulated its own SOE-restructuring programme, which for a large part was based on the blueprint. This programme emphasized the public service and social functions of soes by setting three conditions: that the level of service is maintained; that the accessibility of services is maintained; and that the restructuring does not increase the economic burden on the state. The large coalition on which

https://huma.or.id/wp-content/uploads/20o6/o5/Media-Indonesia-29-Juli-2004-PK -UU-Sumber-Daya-Air-No-7--2004-Diajukan-ke-MK.pdf (accessed 18-10-2018).

14 Since enacted in 2004, Law No. 7 Year 2004 concerning Water Resources has been tested several times in the Constitutional Court. With the Constitutional Court Decision Number 85/PUU-IX/2013, the court revoked the enactment of Law No. 7 Year 2004 and reenacted Law No. 11 Year 1974 concerning Water Resources. On 17 September 2019, the Indonesian parliament approved a new Water Resources Law (Law No. 17 Year 2019) in which the water rights of citizens and farmers are restated. 

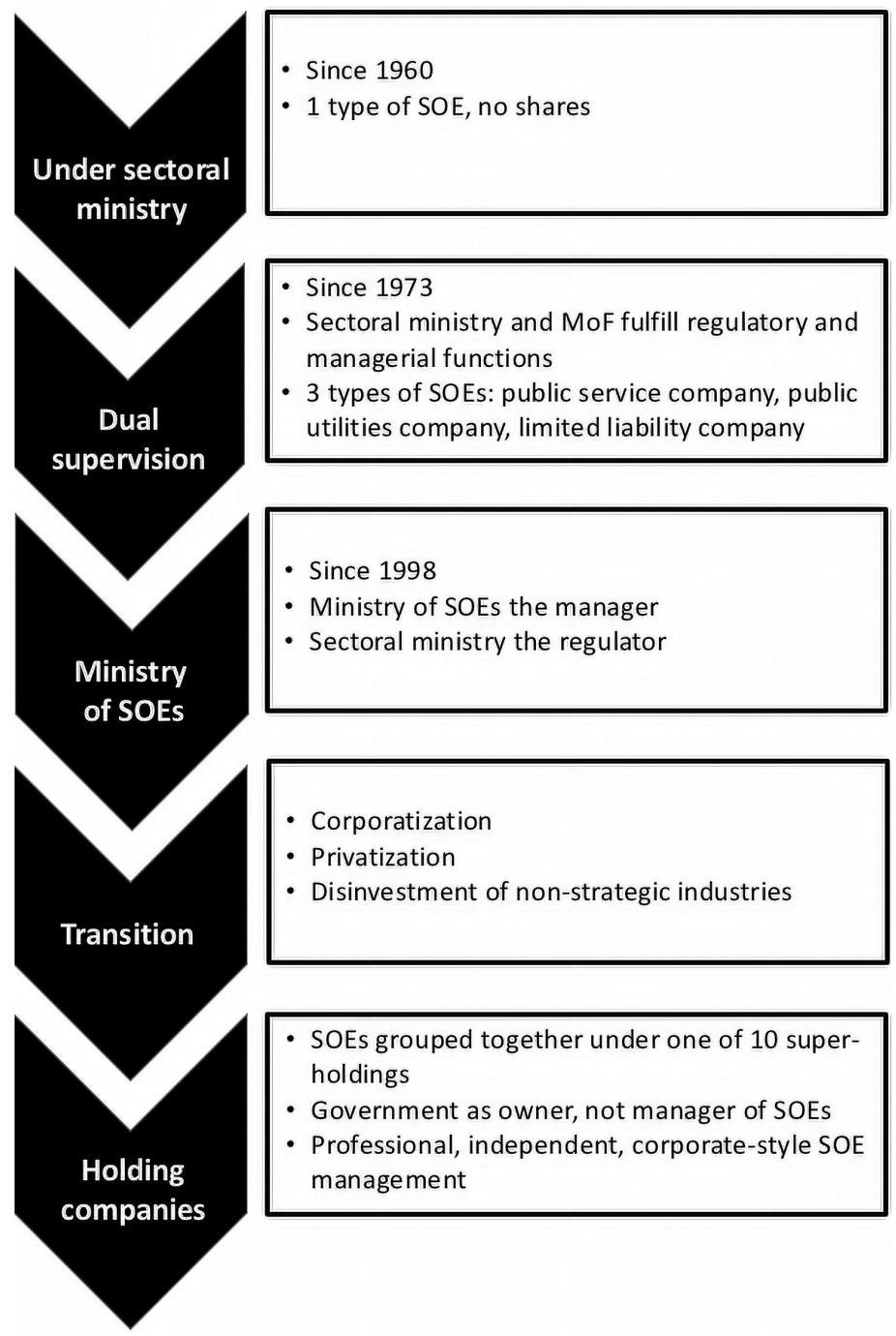

FIGURE 1 The development of SOE s according to the 1998 soe blueprint TAKEN FROM MOELJONO (2004:13-4)

President Wahid's government relied, however, was highly instable. In 2001, the minister of soes was replaced and then the Ministry of soes was abolished altogether. Supervision of soe s was returned to the MoF and the sectoral ministries.

The SOE development plan was not implemented. That same year (2001), President Wahid was impeached and Vice-President Megawati Soekarnoputri was sworn in as the fifth president of Indonesia. President Megawati reinstated 
the Ministry of SOEs. In 2002 the ministry presented its restructuring programme (2002-2006), aimed at partial (not full) privatization of soes. The stated objective was to create competitive and hybrid soes, but the plan was not as clear-cut and comprehensive as the 1998 blueprint had been. On 20 May 2003, the new law on soes was adopted.

The five goals of soes mentioned in Article 2 paragraph (1) of Law No. 19 of 2003 on soEs relate to economic and social development. They are: contributing to the development of the national economy and increasing the income of the state; profit maximization; offering a public function by providing public goods and public services of high quality to fulfil the basic needs of the people; becoming pioneers in segments where private firms and corporations are not yet active; and supporting the initiatives of entrepreneurs from underprivileged groups, corporations, and local communities. A single soE does not need to fulfil all these goals at once, which has raised concerns that policies will focus on state revenues and profit maximization only while ignoring social functions..$^{15}$ The law seeks to increase efficiency of soes in two ways: through the corporatization of the management of soes and through (partial) privatization. The corporatization of management includes the implementation of the international standards of good corporate governance. After the good corporate governance standards have been implemented, the next step is (partial) privatization.

Privatization of soes, however, never really took off after the Reformasi (2004-2015). Despite the stated preference for privatization in the SOE Law, in practice there was insufficient political support for a large-scale overhaul of SOE s. Privatization progressed slowly in this context of strong opposition. The main problem was that the civil and military bureaucrats who controlled the companies were not willing to give up their vested interests in SOEs (Sungkar 2008:111). Citizens' concerns on the issue of soes and the bureaucrats' vested interests sometimes aligned, while at other times they collided, for instance in the forestry and plantation sectors (Lucas and Warren 2003).

Privatization took the form of partial privatizations of the largest limited liability companies, with the government maintaining a majority of the shares (Kim 2018). Between 2004 and 2017, eight companies were partly privatized. The fall in the number of soes from 159 to 115 in this time period (see Table 2), is solely the result of mergers carried out with the objective of making soes more efficient and profitable before 'going public'.

15 See also 'Kembali mempersoalkan peran negara dalam UU BUMN', Hukumonline.com, 10-2-2018. https://www.hukumonline.com/berita/baca/lt5a7eb75ofo44e/kembali -mempersoalkan-peran-negara-dalam-uu-bumn/ (accessed 23-10-2019). 
TABLE 2 Number of SOE S

\section{Public service Public utility Limited liability Publicly listed company company company company}

Year

Total

\begin{tabular}{lrrrrr}
\hline 2004 & 14 & 13 & 120 & 12 & 159 \\
2005 & 0 & 13 & 115 & 12 & 140 \\
2006 & 0 & 13 & 115 & 12 & 140 \\
2007 & 0 & 14 & 113 & 14 & 141 \\
2008 & 0 & 14 & 114 & 14 & 142 \\
2009 & 0 & 14 & 112 & 15 & 141 \\
2010 & 0 & 14 & 110 & 17 & 141 \\
2011 & 0 & 14 & 108 & 18 & 140 \\
2012 & 0 & 14 & 107 & 19 & 140 \\
2013 & 0 & 14 & 105 & 20 & 139 \\
2014 & 0 & 14 & 85 & 20 & 119 \\
2015 & 0 & 14 & 84 & 20 & 118 \\
2016 & 0 & 14 & 84 & 20 & 118 \\
2017 & 0 & 14 & 84 & 17 & 115 \\
\hline
\end{tabular}

SOURCE: MINISTRY OF SOES 2018 HTTP://BUMN.GO.ID/HALAMAN/0-STATISTIK-JUMLAH -BUMN (ACCESSED 7 FEBRUARY 2020)

\section{$7 \quad$ Restructuring under President Jokowi (2015-now)}

Under the administration of President Jokowi, the focus of policies pertaining to SOEs has changed: the creation of SOE holdings-not privatization-has become the priority. The government turned soes into important vehicles of economic development-especially the development of infrastructure. During 2015-2016 alone Indonesia invested IDR 115 trillion in SOEs, an annual investment 23 times higher than during the period before (2013-2014) and 2.5 times higher than the total of investments during the previous ten years. A total of 43 companies received state capital investments during 2015-2016, up from three in $2013-2014 .{ }^{16}$ From 2015 to 2019 , around $17 \%$ of the state budget was allocated to infrastructure projects mainly carried out by soes. According to

16 Kyunghoon Kim, 'Indonesia's growing state enterprises: More information needs to be 
the OECD in Indonesia, 'sOE s are more pervasive across the economy than in any country in the OECD's Product Market Regulation database except China.'17

The rationale for the increased role of SOEs in Indonesia's economic infrastructure development is pragmatic. SOE s are the only entities that are likely to obtain sufficient capital to carry out such large-scale infrastructure projects. As Indonesia has insufficient tax revenues - it has the lowest tax-revenue ratio in the Asian Pacific region ${ }^{18}$ and does not manage to attract sufficient foreign direct investment to finance large-scale infrastructural projects - the government needs SOE s to both finance and carry out the projects.

According to the Indonesian government, the way for soes to generate more funds is by organizing them into holdings. Ministry secretary Imam Apriyanto has recently stated that privatization of soE $\mathrm{s}$ is no longer on the agenda, as the main focus is on setting up holding programmes for infrastructure, housing, pharmaceuticals, and asset management. He continued: 'By doing this, we can speed up the process of getting extra funds without using the state budget.'19 Smaller cement, fertilizer, plantation, and forestry soe s have been merged with this objective in mind. ${ }^{20}$

The budget allocated to soEs is not always managed well. Since 2015, the Komisi Pemberantasan Korupsi (KPK; the Corruption Eradication Commission; hereafter КРК) has filed 241 corruption cases related to infrastructure projects. ${ }^{21}$ Corruption by soes is persistent in other sectors as well and involves some of the most renowned sOEs in Indonesia. The list of KPK suspects for the

shared with shareholders', pinterpolitik.com, 12-3-2018. https://pinterpolitik.com/indone sias-growing-state-enterprises-information-needs-shared-shareholders/ (accessed 23-10 $-2019)$.

17 OECD, 'OECD economic surveys, Indonesia, October 2018-Overview'. http://www.oecd .org/eco/surveys/Indonesia-2018-OECD-economic-survey-overview.pdf (accessed 23-102019).

18 OECD, 'Revenue statistics in Asian and Pacific economies, 2019 - Indonesia: Tax-to-GDP ratio'. https://www.oecd.org/tax/tax-policy/revenue-statistics-asia-and-pacific-indonesia .pdf (accessed 23-10-2019).

19 Stefanno Reinard Sulaiman, 'How are soe s performing under Jokowi?', The Jakarta Post, 123-2019. https://www.thejakartapost.com/news/2019/o3/11/how-are-soes-performing-und er-jokowi.html (accessed 23-10-2019).

20 Nikkei Asian Review, 'Jakarta accelerates merger of state-owned energy mining companies', 12-1-2017. https://asia.nikkei.com/Economy/Jakarta-accelerates-merger-of-state-own ed-energy-mining-companies (accessed 15-10-2018).

21 Akhmad Misbakhul Hasan, 'Ahead of the second debate, get the lowdown on infrastructure under Jokowi', Indonesia at Melbourne, 14-2-2019. https://indonesiaatmelbourne .unimelb.edu.au/ahead-of-the-second-debate-get-the-lowdown-on-infrastructure-under -jokowi/ (accessed 23-10-2019). [Policy in Focus.] 
period 2017-2019 is long and includes high-ranked managers of soes in the electricity sector (PT PLN), the steel sector (PT Krakatau Steel), airport development (PT Angkasa Pura II), fisheries (Perindo), plantations (PT Perkebunan Nusantara III), oil and gas (Pertamina), airlines (PT Garuda), harbours (PT Pelindo), ship construction (PT PAL), and insurances (PT Asuransi Jasindo). ${ }^{22}$ Pending the elections of 2019, the government disregarded persistent managerial problems at soes. However, after it was clear that President Jokowi had won the elections, the re-appointed minister of finance, Sri Mulyani, scolded the soe bosses for continued practices of corruption. ${ }^{23}$

Despite Jokowi's pleas for a revolusi mental (mental revolution) and more efficiency, today's restructuring of soe s primarily takes place as a way to secure more funding for projects, while improving management and accountability appear to be a secondary concern. Efficiency and productivity are mainly assessed by measuring how much of the projects have been realized $(3,000 \mathrm{~km}$ of roads, 40,00om of bridges, toll roads, railways, airports), ${ }^{24}$ as well as the tax and non-tax state income soes generate. In view of the weak performance of Jokowi's predecessors in developing the infrastructure, this output is indeed impressive; yet, managerial issues remain and require just as much attention.

When the blueprint for SOEs was developed in 1998, the rationale for creating holding companies was threefold: synergy between soe s and economies of scale will reduce inefficiencies; centralized holdings will decrease the influence of politicians and sectoral ministries over soes' management; and the focus on holdings will reduce the supervisory load for the government. According to the blueprint, the processes of corporatization and partial privatization must precede the establishment of holding companies. The OECD maintains that President Jokowi's administration rushes the creation of holdings, without creating the required corporate and regulatory infrastructure first. ${ }^{25}$

22 Achmad Dwi Afriyadi, 'Disebut Sri Mulyani pengkhianat, ini daftar bos BUmN terbelit korupsi', detikFinance, 4-10-2019. https://finance.detik.com/berita-ekonomi-bisnis/d-4733 506/disebut-sri-mulyani-pengkhianat-ini-daftar-bos-bumn-terbelit-korupsi/3 (accessed 23-10-2019).

23 Trio Hamdani, 'Sebut bos Bumn pengkhianat, Sri Mulyani: Itu uang rakyat!', detikFinance, 4-10-2019. https://finance.detik.com/berita-ekonomi-bisnis/d-4733395/sebut-bos-bumn -korup-pengkhianat-sri-mulyani-itu-uang-rakyat (accessed 23-20-2019).

24 Akhmad Misbakhul Hasan, 'Ahead of the second debate, get the lowdown on infrastructure under Jokowi'.

25 OECD, 'OECD economic surveys, Indonesia, October 2018-Overview'. http://www.oecd .org/eco/surveys/Indonesia-2018-OECD-economic-survey-overview.pdf (accessed 23-102019). 
Indonesia looks at neighbouring countries Singapore and Malaysia, which have successfully improved the performance of soes by organizing them into state-owned holdings. However, in these countries managerial reforms preceded the structural reforms. As Kim (2018:326) phrases it: 'It is not the SOE ownership structure that has automatically resulted in market-oriented behaviour of, for example, Singaporean soes, but rather the institutional and legal basis that have supported more autonomous corporate strategy-making mechanisms while improving oversight apparatus.' Indonesia now organizes the holdings first and attempts to improve the soes' checks and controls and accountability in the process. Policies pertaining to PSAs see a similar course of action: structural reforms are introduced while lacking the required strong regulatory framework.

\section{The Creation of Public Service Agencies (2004-now)}

In 2004, during the administration of President Megawati Sukarnoputri, a new type of government agency was introduced: the PSA. ${ }^{26}$ Undang-Undang No. 1 Tahun 2004 tentang Perbendaharaan Negara (Law No. 1 of 2004 on the State Treasury; hereafter the 2004 State Treasury Law) defines a PSA as 'an institution within the sphere of the government which provides public services in the form of goods or services, is non-profit, based on the principles of efficiency and productivity.'. ${ }^{27}$ The main difference with other government agencies is that PSAs have a larger autonomy to manage their budget and are allowed to conduct commercial activities to supplement their budget (Waluyo 2018).

Further, according to Article 68 of the 2004 State Treasury Law, PSAs are formed to enhance public services for the welfare and intelligence of society; have assets that are state-owned, not separated from the state budget, and managed and utilized to carry out the activities of the PSA; and fall under dual supervision: financial supervision by the MoF and technical supervision by the sectoral ministry. PSAs' management form, especially their dual supervision and relative freedom to manage their financial affairs, is very similar to the managerial organization of the public service companies prior to their placement under the Ministry of soes (see Table 1). This dual management by the sectoral ministry and the MoF could not tackle persistent managerial issues pertaining to soes and, as we argue, will face the same issues with PSAs as long

26 Introduced through Law No. 1 of 2004 on the State Treasury.

27 Article 1 (23). 


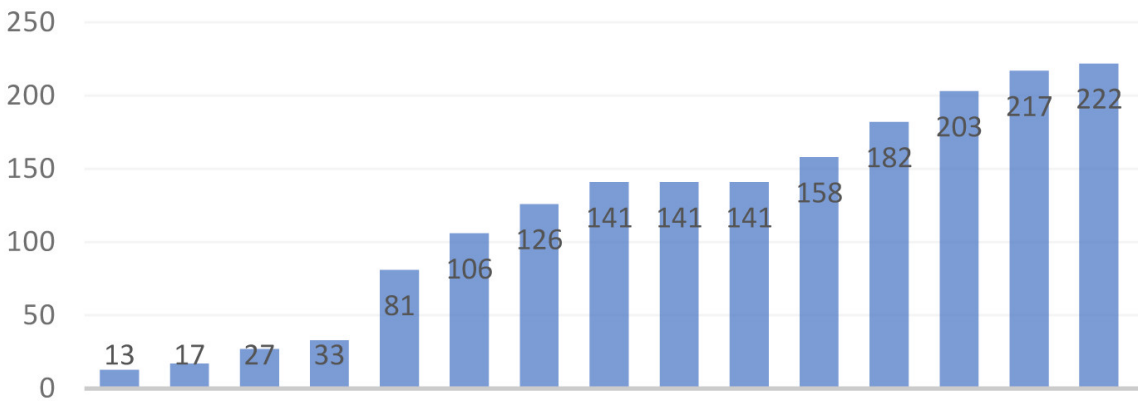

200520062007200820092010201120122013201420152016201720182019

\section{number of PSAs}

FIGURE 2 Number of national PSAs in Indonesia 2005-2019 WEBSITE OF MINISTRY OF FINANCE 2019, HTTP://BLU.DJPBN.KEMENKEU.GO .ID/ (ACCESSED 7 FEBRUARY 2019)

as it lacks a strong regulatory framework which is based on a clear ideological foundation.

PSA s have substantial influence on the tariffs they offer. The management of PSAs proposes the height of the tariffs (the Minister of Finance's approval is required). According to the website of PSAs, the PSA management must consider four aspects in implementing their financial autonomy: continuity and improvement of services; the purchasing power within society; the principles of justice and fairness; and healthy competition. ${ }^{28}$ Financial considerations are dominant. The continuity and improvement of public services are monitored through the financial reports of PSAs, whereas the quality of services is not mentioned. Purchasing power is defined as the ability and willingness of the people to pay for services. The principles of justice and fairness are to mean that the economic backgrounds of the service receivers must be considered in tariff setting and that tariffs must be consistent with government regulations. The principle of healthy competition means that PSAs must charge tariffs that are similar to those charged by private players in similar market circumstancessuch tariffs are considered as proper (wajar). This means that, with the exception of applicable government standards, market prices are leading.

Over the past 15 years, the government of Indonesia has established 222 PSA S in 22 ministries (see Figure 2). More than 90\% of the PSAs are active in the health and education sectors (see Figure 3 ). The other $10 \%$ manage indus-

28 As mentioned under 'profile', 'layanan' (services) on the PSA (BLU) page on the website of the MoF. http://blu.djpbn.kemenkeu.go.id/index.php (accessed 23-10-2019). 


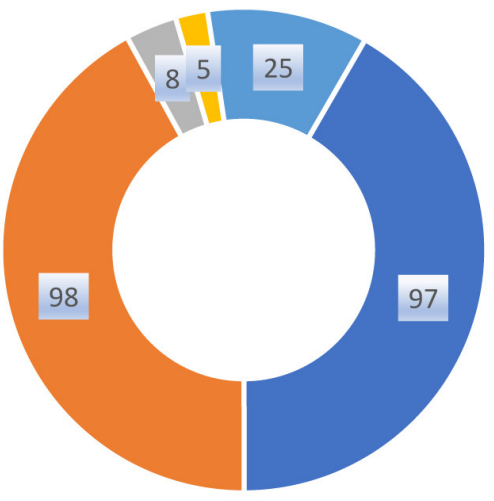

- Health - Education - Finance - Assets - Other
FIGURE 3

Number of PSAs per sector (2018) WEBSITE OF MINISTRY OF FINANCE 2019, HTTP://BLU.DJPBN .KEMENKEU.GO.ID/ (ACCESSED 23 OCTOBER 2019)

trial estates and financial services for cooperatives, small businesses, as well as micro- and medium-sized enterprises. Figure 3 shows that a large majority $(90 \%)$ of PSA s operate in the health and educational sectors. Government spending in the health sector (IDR 123.1 trillion, or $5 \%$ of the 2019 state budget) and education sector (IDR 492.5, or $20 \%$ of the 2019 state budget) is substantial in absolute terms ${ }^{29}$ but still low compared to GDP. ${ }^{30}$

The government presents the establishment of PSAs as a success, stressing the positive effects on the state's budget. In 2018, revenues generated by PSAs contributed IDR 55.4 trillion to the state budget, more than the projected IDR 43,3 trillion, up from IDR 29.7 trillion in 2014. The largest contributor, with IDR 11.5 trillion, was the Badan Pengelola Dana Perkebunan Kelapa Sawit (the Office for the Management of Palm Oil Plantations Funds). ${ }^{31}$ The performance of PSAs in other areas, such as improving accountability and public services, is much weaker. For instance, in the education sector, both the Kementerian Riset dan Teknologi (Kemenristek, Ministry of Research and Technology) and the universities, when confronted with the difficulty of ensuring poor students' access to higher education, ignore the problems underprivileged

29 Kementerian Keuangan Republik Indonesia, 'Informasi APBN 2019: APBN untuk mendorong investasi dan daya saing melalui pembangunan sumber daya manusia'. https://www .kemenkeu.go.id/media/11213/buku-informasi-apbn-2019.pdf (accessed 23-10-2019).

30 For 2017 education public expenditure to GDP was $3.6 \%$, while healthcare public expenditure to GDP was $2.8 \%$. ASEAN, 'ASEAN key figures 2018'. https://www.aseanstats.org/wp -content/uploads/2018/12/ASEAN-Key-Figures-2018.pdf (accessed 23-10-2019).

31 N. Nuriman Jayabuana, 'BLU menyumbang penerimaan negara Rp. 554 trilliun di sepanjang 2018', Bisnis.com, 26-2-2019. https://ekonomi.bisnis.com/read/2019o226/9/893578/ blu-menyumbang-penerimaan-negara-rp554-triliun-di-sepanjang-2018 (accessed 23-10 $-2019)$. 
students experience in accessing those funds; ${ }^{32}$ instead, they point to special grants for underprivileged students and cross-subsidization that are intended to keep public services accessible. ${ }^{33}$

The case of the national health insurance below will illustrate how difficult it is to prevent conflicts of interests when large government funds are involved. The case demonstrates how informality-related problems persisted after the management of state insurance funds was transferred from an SOE to a PSA, from a profit-oriented to a non-profit organization.

\section{9}

\section{Restructuring of the Universal State Health Insurance}

The reforms in the health insurance system took place in the context of the constitutional amendments of 2002, especially Article 34 (2) of the Constitution, which establishes the right to social security. In 2004 a new social security law was introduced to regulate universal coverage of its national public health insurances. A public health insurance scheme for the poor (Asuransi Kesehatan Miskin, Askeskin) was rapidly developed in order to increase health insurance coverage rate in Indonesia. The SOE PT Askes was given the responsibility to manage the Askeskin programme, renamed the Public Health Insurance (Jaminan Kesehatan Masyarakat or Jamkesmas) in 2008. Under the Askeskin and Jamkesmas programmes the coverage rate of health insurances in Indonesia increased significantly, from $20 \%$ in 2005 to $49 \%$ in 2014 (Rokx et al. 2009). Despite this success, the programmes experienced many problems, including a lack of funds, conflict of interests, lack of supervision, and fraud (Pisani, Kok, and Nugroho 2017).

To tackle these problems, the public health insurance programme was reorganized under the government of Joko Widodo. In 2014 responsibility for the

32 In practice, underprivileged students who are eligible for subsidies or grants face many bureaucratic hurdles when applying for grants, while accountability of universities is weak. See Dadan Rizwan Fauzi, 'Dinamika penerapan sistem uang kuliah tunggal (UKT) di PTN', kompasiana.com, 27-2-2017. https://www.kompasiana.com/dadanrizwan/58b31b18b 27e6rbcoa4f $\mathrm{f}_{35} /$ dinamika-penerapan-sistem-uang-kuliah-tunggal-ukt-di-ptn?page=1 (accessed 24-10-2019).

33 'Menristekdikti: Mahasiswa tak mampu bisa kuliah di Kedokteran' Berita UIN Online, 24-32017. https://www.uinjkt.ac.id/id/menristekdikti-mahasiswa-tak-mampu-bisa-kuliah-di -kedokteran/ (accessed 23-10-2019); 'Rektor PTN diminta perhatikan kemampuan mahasiswa bayar uang pangkal', Jawa Pos, 19-7-2019. https://www.jawapos.com/nasional/pendid ikan/19/o7/2019/rektor-ptn-diminta-perhatikan-kemampuan-mahasiswa-bayar-uang-pa ngkal/ (accessed 24-10-2019). 
public health insurance scheme was given to the Badan Penyelenggaraan Jaminan Social (вРJs, Body for the Organization of Social Security), an independent government body that operates directly under the Kantor Kepresidenan (Office of the President), as the commercial function of the SOE PT Askes was deemed to be in conflict with the social service function it had. From a social perspective, the introduction of BPJS has been a success, as the number of Indonesians who are insured had increased from 145 million persons in 2014 (coverage of $49 \%$ of the population), of whom 86 million were subsidized at the start of the programme (Hidayat et al. 2015), to 203 million persons (coverage of $76 \%$ ) by 2018,120 million of whom were subsidized (the Indonesian Health Systems Group 2018). However, management of the BPJS schemes remains problematic. By 2018 BPJ S had a negative balance of IDR 23 trillion and required a financial injection of IDR 15.6 trillion. Besides a hasty introduction, conflicts of interests between stakeholders and insufficient supervision continued, facilitating fraud. ${ }^{34}$ An earlier study found that PSAs did not improve service delivery in the health sector (Damhuri 2011). This means that the managerial problems attributed to the profit-oriented SOE PT Askes persisted under the non-profit PSA BPJS. Changing the outward structure of Indonesia's state health insurance management did not solve managerial problems that are related to informality of public management and lack of controlling mechanisms.

\section{Restructuring Higher Education}

In the education sector, the other sector in which most PSAs operate, the Reformasi era led to calls for autonomy. Under the New Order regime, institutions of higher education were placed under strict bureaucratic control, both financially and ideologically (Rosser 2018). Hence, already in the year 1999, five years prior to the introduction of PSAs, four top universities were granted the status of Badan Hukum Milik Negara (State-Owned Legal Body, hereafter вн мN) by presidential decree with a large autonomy to arrange their own financial affairs and to develop their own curriculum: Universitas Indonesia, Universitas Gadjah Mada, Institut Pertanian Bogor, and Institut Teknologi Bogor. In 2006 three other universities obtained a B HM N-PSA status. From 2005 onwards, the possibility arose to create PSA s-also in the education sector. In 2008 the

34 Elba Damhuri, 'Solusi selamatkan вpjs kesehatan', Republika, 11-1-2019. https://republika .co.id/berita/pl4nıw440/solusi-selamatkan-bpjs-kesehatan (accessed 23-10-2019). 
first universities with sufficient capacity to manage their own finances were given the regular status of Badan Layanan Umum, (BLU, hereafter BLU-PSA).

As the most prestigious universities received the PSA status of BHMN and the second-best, the status of BLU, the formal status of a university became associated with its social status: the more financial autonomy, the more prestigious the university. The most prestigious universities increased their tuition fees significantly after they had been granted the freedom to do so. Because they were the model universities, other universities followed suit, not only B LU-PSAs but also those institutes for higher education that were still fully under control of the Kementerian Pendidikan dan Budaya (Ministry of Education and Culture) (Susanti 2011).

In 2009, the government adopted Undang-Undang No. 9 Tahun 2009 tentang Badan Hukum Pendidikan (Law No. 9 of 2009 on Education Legal Entity; hereafter the BнP Law). The underlying philosophy of the law was that academic freedom must be matched with managerial and financial autonomy in order to improve the quality of education. The universities which had the status of BHMN based on a presidential decree-and therefore had to operate in an unclear legal framework - now were granted the status of вн P in accordance with the new law and received a high degree of autonomy (Ngo and Meek 2019). It was envisioned in the law that in the end all institutes of higher learningincluding private ones - would take the form of а вн $\mathrm{P}$.

The new law met with strong resistance from within the education sectorespecially from private institutions - and from activists, who feared that the costs for higher education would rise further if the educational sector would be run based on market forces (Rosser 2018). The BH P Law was sent to the Constitutional Court for review. In 2010 the Constitutional Court annulled the law, as it ruled that the government disregarded its constitutional responsibility to ensure accessibility of education by giving a large financial responsibility to the universities and their overarching body. The Constitutional Court especially considered as problematic the fact that normal bankruptcy procedures would apply to state institutes of higher learning. ${ }^{35}$ Following the ruling, universities that had received the BHP status retained their former status as BHMN.

Undang-Undang No. 12 Tahun 2012 tentang Pendidikan Tinggi (Law No. 12 of 2012 on Higher Education; hereafter the 2012 Law on Higher Education) sparked far less controversy. It provided universities with a similar level of

35 'M K batalkan Uu Badan Hukum Pendidikan', Hukumonline, 31-3-2010. https://www.hukum online.com/berita/baca/lt4bb37a39de6cc/mk-batalkan-uu-badan-hukum-pendidikan/ (accessed 23-10-2019). 
autonomy as the withdrawn 2009 BHP Law but did not stipulate the autonomous legal entity, now simply called Badan Hukum (в н, Legal Entities), to become the single institution for higher education in the future. As a result of the 2012 Law on Higher Education, three types of institutions for higher education exist today. First, satuan kerja (satker, units) that are fully placed under the Ministry of Education and Culture, or, in case of religion-based state institutions of higher education, the Ministry of Religion (Kementerian Agama). Second, institutions with the status of a BLU-PSA and with dual supervision of the Ministry of Research and Technology and the MoF. Third, the Badan Hukum-PSA under supervision of the Ministry of Research and Technology. A Badan Hukum university has a stronger mandate to charge relatively high tuition fees, as it mainly looks at the financial capacity of its targeted students and no longer at the purchasing power of society as a whole (see Figure 3). In 2016 state universities without managerial autonomy were still in the majority: 11 universities had the status of РT-BH; 24, the status of BLU; and 85, the status of satuan kerja, which means that they fully fall under the management of the Ministry of Education and Culture. ${ }^{36}$

Greater autonomy has resulted in a more diversified income for the universities. Whereas state universities in the 199os were almost entirely dependent on state funding, today only $20 \%$ of the budget of Indonesia's state universities comes from state funding, while $60 \%$ comes from tuition fees and an additional $20 \%$ from service activities (Ngo and Meek 2019). However, the financial autonomy has not yet produced the intended large improvement in the quality of education and research in Indonesia. As the World Bank pointed out in its report on education financing in Indonesia (World Bank 2013), increased funding has not improved the organization of education within state universities. The quality of education in Indonesia still lags behind other countries in Southeast Asia (Rosser 2018). Unclear or complex regulations have not disappeared, corruption issues persist, and state supervision is weak (Komisi Pemberantasan Korupsi 2019).

The World Bank, in its review of the project 'Managing Higher Education for Relevance and Efficiency', which ran from 2006 to 2012, still recommended 'more scope for revenue generation and charging appropriate tuition, although increases in tuition have been resisted to some extent by some sectors of the public' (World Bank 2015:4). However, as early as its 2013 report on financing education, the World Bank was warning that fees had become so high that they

36 See the website of the Ministery for Research and Technology, 'Seputar PTN-BH, PTN-BLU, PTN-Satker dan PTN-Baru', ristekdikti.go.id, 16-5-2016. http://lidikti12.ristekdikti.go.id/2016/ 05/16/seputar-ptn-bh-ptn-blu-ptn-satker-dan-ptn-baru.html (accessed 23-10-2019). 
might come at the cost of the accessibility of tertiary education for the poor (World Bank 2013). Since this warning in 2013, tuition fees at Indonesia's universities have risen $15 \%$ annually; they are expected to double in the next five years and quadruple in the next ten years. ${ }^{37}$

The significantly higher amount of non-state funding has not resulted in improvements to universities' main functions, namely providing appropriate salaries for university staff and funding for research activities. Consequently, researchers in Indonesia 'often turn to other work to supplement their income', mainly short-term projects (Ngo and Meek 2019:23). The government's claim of efficiency and effectiveness is difficult to maintain as long as the ultimate outcome of all the extra funding generated by tuition fees is neither better education and research nor improved management and accountability (Rosser 2018:19-20). Moreover, the new system creates a new problem: it impairs on the accessibility of higher education for the poorer segment of society, as access by underprivileged students to cross-subsidization and student grants schemes remains low.

\section{Issues with New Public Management in Indonesia}

The introduction of PSAs was intended to create more efficient and accountable government institutions. The cases of the health insurance and higher education do not indicate that restructuring has increased efficiency. On the contrary, in his analysis of Indonesia's PSA system, Jin-Wook Choi explains how the autonomy and flexibility of PSAs in financial management has decreased the accountability of PSA s. This resulted in a lack of governmental supervision over how PSA s' personnel and financial affairs are managed. For example, in 2014, 70 staff members at the Direktorat Badan Layanan Umum (Directorate of PSAs) at the MoF, many without specific qualifications for this task, had to monitor and evaluate more than 130 PSAs (Choi 2016:120).

Performance improvement is the raison d' être of PSAs. A PSA is awarded a high degree of flexibility and autonomy in personnel and financial management under the premise that it will provide public services in a more efficient and effective manner. The success story of PSAs presented by the government, however, originates from a narrow focus on the state budget and non-tax

37 Yohanes Enggar Harususilo, 'Inflasi pendidikan tinggi, berapa biaya kuliah 5 dan 10 tahun lagi?', Kompas.com, 9-10-2018. https://edukasi.kompas.com/read/2018/10/og/13261841/infl asi-pendidikan-tinggi-berapa-biaya-kuliah-5-dan-10-tahun-lagi (accessed 23-10-2019). 
revenues. Moreover, here are indications that at least some of the reported successes in terms of revenues are the result of inadequate financial reports. Research into the financial reports of two state hospitals in Central Java found that the salaries of civil servants that are directly paid by the ministry were not included in financial reports. PSAs that employ civil servants therefore reported a much too positive financial performance, as if their employees worked for free (Ambariani 2014). Similar problems with disregarded employment costs are mentioned by Choi (Choi 2016).

A research report about PSAs in Indonesia by a research consortium led by the Korean Ministry of Strategy and Finance and commissioned by the government of Indonesia confirms that financial autonomy has not led to an improvement of the performance of PSAs (Ministry of Strategy and Finance Republic of Korea 2015). The report identifies multiple problems in Indonesia's PSA system, which can be subsumed under three main categories: governance structure; financial management; and performance management. With regard to governance structure, the report mentioned three problems. First, current regulations neither define the detailed roles and responsibilities of the MoF, sectoral ministries, and PSAs adequately, nor do they specify procedures and mechanisms regarding the management of PSAs. Second, there is a shortage of manpower and capacity within the Directorate of PSAs. Thirdly, the PSAs' governance lacks consistent and coherent managerial principles. Different types of PSAs with different forms of financial autonomy exist, which complicates supervision.

With regard to financial management, the ambiguity of budget composition causes problems. First, civil servants' salaries, operational expenditure, and the capital expenditure of the PSA are taken from the national budget and are not managed by the PSAs themselves. Ideally, PSAs manage all expenses related to their operations and they certainly must be included in financial reports. Second, there is no well-structured performance appraisal system, meaning that the MoF is not able to control inefficient spending of PSAs. Third, increasing expenditure of PSAs is not followed by improved performance. While many PSAs succeed in increasing their budget, they tend to increase unnecessary and redundant inputs, causing inefficiency in budget spending.

With regard to performance management, the report identified some key problems. First, performance appraisal in Indonesia is not linked to the PSAs' budget. High-performing PSAs are not rewarded and low-performing PSA s not punished through a budget reduction. There is a lack of incentives for PSAs to improve performance. Second, the assessment model for PSAs' financial performance is inadequate. The assessed KPI s do not represent all the dimensions of operation and management of a PSA. 
In short, the report cautions that autonomy of public agencies must not lead to weak supervision. When financial autonomy is not met with accountability, this increased freedom can be misused by the management. Additionally, we argue that the problematic performance of PSAs must also be traced back to the unclear ideological foundation of PSAs. According to its legal definition, a PSA should not prioritize profit but public service. In practice, there is a pattern in which the government measures a PSA's success by calculating the revenues that it has generated, without looking at its overall performance as service delivery provider, and without assessing adverse consequences. PSA $s$ mainly move in the education and health sectors, where the state has a constitutional responsibility to maintain accessibility. Autonomy has denoted an increase in service fees, which are partly paid by government subsidies-thus potentially impacting the sustainability, quality, and accessibility of subsidized state health care and education services for the poor and the lower middle class.

The comparison of SOE s and PSA s has enabled us to identify patterns concerning public sector restructuring in Indonesia. Restructuring in the line of New Public Management was considered necessary because of a lack of state budget due to low tax revenues. On paper New Public Management reforms require a formal corporate culture (corporatization). However, as changing an informal management culture is proven difficult and politically sensitive, new structures were generally introduced before corporatization and formalization processes had taken root.

The case of soes demonstrates how policies aiming to achieve their partial privatization took place in a political context in which support for a nationalist economy remained strong and restructuring aimed at privatization mostly took place in a context of insufficient political support for privatization itself. As a result of political compromises, the new structures lacked sufficient control mechanisms and a clear division of tasks among the relevant government institutions. Thus, within these public sector institutions, an environment was created in which a culture of informality could continue. New structures created the illusion of reform, while in reality core issues that lay at the root of the informality of their management remained untouched and accountability remained weak.

The success of restructuring in terms of efficiency depends on how one defines efficiency. PSA s are efficient from the perspective of the state budget, as 
they manage to create much more revenue for the state than before the agency was introduced. The opposite conclusion is just as plausible: PSAs are inefficient as they do not improve public services, despite the much-higher revenues they generate. Moreover, reforms have not led to improved accountability.

Because restructuring took place without first creating the necessary regulatory and ideological framework and without changing the culture of informality, the implementation of restructuring depends strongly on the personal qualities of those in the highest ranks of the government. The persuasive power of President Jokowi, the MoF's Sri Mulyani, and the then minister of soes Rini Soemarno and others were key in getting bureaucratic reforms through the system during the first term of Jokowi's government. Patrimonialismnot a change of mindset or a revolusi mental within the bureaucracy - is the foundation of current bureaucratic reforms in Indonesia (Rosser 2018; Gaus, Sultan and Basri 2017). Today, there are signs that within Jokowi's broad coalition, opposition against bureaucracy reforms is rising, ${ }^{38}$ which may lead to less determination in implementing reforms.

We believe that the persuasive power of key ministers in President Jokowi's administration should be used to provide a clear justification for the establishment of PSAs. A 'clear justification' in our perspective refers to a clear philosophical foundation in which the social functions of PSAs and SOEs are underlined. Reforms in education and health sectors cannot be solely based on patrimonialism to be sustainable; they need strong financial control mechanisms and an accountability that values financial and social objectives equally. Quality of management and services should be just as important as revenues, and accessibility of services as important as bureaucratic reforms. Such an ideological foundation is essential to bringing about change in the bureaucratic culture-a real revolusi mental.

\section{References}

Ambariani, Anastasia Susty (2014). 'Hospital financial performance in the Indonesian national health insurance era', Review of Integrative Business and Economic Research 4-1:367-79. http://e-journal.uajy.ac.id/17742/ (accessed 28-10-2019).

Bel, Germà and Marc Esteve (2019). 'Is private production of hospital services cheaper than public production? A meta-regression of public versus private costs and

38 Elizabeth Matsangou, 'What does the future hold for Indonesia during Jokowi's second term?', World Finance, 9-8-2019. https://www.worldfinance.com/markets/what-does-the -future-hold-for-indonesia-during-jokowis-second-term (accessed 23-10-2019). 
efficiency for hospitals', International Public Management Journal 23:1, 1-24. DoI: 10.1080/10967494.2019.1622613 (accessed 28-10-2019).

Bel, Germà and Mildred Warner (2008). 'Does privatization of solid waste and water services reduce costs? A review of empirical studies', Resources, Conservation \& Recycling 52-12:1337-48. DoI: 10.1016/j.resconrec.2008.07.014 (accessed 28-10-2019).

Booth, Anne and Peter McCawley (1981). The Indonesian economy during the Soeharto era. Oxford: Oxford University Press.

Boyne, George A. (1998). Public choice theory and local government: A comparative analysis of the UK and the USA. Basingstoke: Macmillan.

Bruton, Garry D., Mike W. Peng, David Ahlstrom, and Ciprian V. Stan. (2015). 'Stateowned enterprises around the world as hybrid organizations', Academy of Management Perspectives 29-1:92-114.

Choi, Jin-Wook (2016). 'New public management or mismanagement? The case of public service agency of Indonesia', Journal of Management \& Politics 7-1:104-27.

Damhuri, T. (2011). 'The performance of newly autonomous state agencies in Indonesia: A case study on 12 central government hospitals' [MA thesis, School of Public Policy Management, Korean Development Institute, Seoul].

Diah, Marwah M. (2003). Restrukturisasi BUMN di Indonesia: Privatisasi atau korporatisasi? Jakarta: Literata Lintas Media.

Dick, Howard, Vincent J.H. Houben, J. Thomas Lindblad and Thee Kian Wie (2002). Emergence of a national economy: An economic history of Indonesia, 1800-2000. Sydney: Allen and Unwin.

Engel, Susan N. (2006). 'Where to neoliberalism? The World Bank and the post-Washington consensus in Indonesia and Vietnam', in: A. Vickers and M. Hanlon (eds), Asia reconstructed: Proceedings of the 16th biennial conference of the ASAA, 2006, Wollongong, Australia. Canberra:The Australian National University. http://ro.uow.edu.au/ artspapers/726 (accessed 28-10-2019).

Gaus, Nurdiana, Sultan Sultan and Muhammad Basri (2017). 'State bureaucracy in Indonesia and its reforms: An overview', International Journal of Public Administration 40-8:658-69. DOI: 10.108o/o19oo692.2016.1186179 (accessed 28-10-2019).

Goldeng, Eskil, Leo A. Grunfeld, and Gabriel R.G. Benito (2008). 'The performance differential between private and state-owned enterprises: The roles of ownership, management and market structure', Journal of Management Studies 45-7:124473 .

Hatta, Mohammad. (1979). Ekonomi terpimpin. First edition 1959. Jakarta: Penerbit Mutiara.

Heath, Joseph and Wayne Norman (2004). 'Stakeholder theory, corporate governance and public management. What can the history of state-run enterprises teach us in the post-Enron era?', Journal of Business Ethics 53-3:247-65.

Hidayat, Budi, Munidharno, Jiř́ Němec, Viktoria Rabovskaja, Cut Sri Rozanna, and 
Julius Spatz (2015). Financial sustainability of the national health insurance in Indonesia: A first year review policy brief. Jakarta: Indonesian-German Social Protection Programme (SPP). http://nbn-resolving.de/urn:nbn:de:101:1-201604225989 (accessed 23-10-2019).

Hood, Christopher (1995). 'The 'New Public Management' in the 1980s: Variations on a theme', Accounting, Organizations and Society 20-2:93-109.

Hossain, Akhand (2005). 'Granger-causality between inflation, money growth, currency devaluation and economic growth in Indonesia, 1951-2002', International Journal of Applied Econometrics and Quantitative Studies 2-3:45-68.

Ilmar, Aminuddin (2012). Hakmenguasai negara dalam privatisasi B UMN. Jakarta: Kencana.

Inoue, Carlos F.K.V., Sergio G. Lazzarini, and Aldo Musacchio (2013). 'Leviathan as a minority shareholder: Firm-level implications of state equity purchases', The Academy of Management Journal 56-6:1775-1801.

Kikeri, Sunita and John Nellis (2002). 'Privatization in competitive sectors: The record today'.https://ssrn.com/abstract=636224 (accessed 28-10-2019)

[World Bank Policy Research Working Paper 286o].

Kim, Kyunghoon (2018). 'Matchmaking: Establishment of state-owned holding companies in Indonesia', Asia \& the Pacific Policy Studies 5 5:313-30.

Komisi Pemberantasan Korupsi (2019). Kajian tata kelola Perguruan Tinggi Kementerian Lembaga (PTKL). Jakarta: KPK.

Kowalski, Przemyslaw, Max Büge, Monika Sztajerowska and Matias Egeland (2013). State-owned enterprises: Trade effects and policy implications. https://doi.org/10.1787/ 5k4869ckqk7l-en (accessed 28-10-2019). [OECD Trade Policy Papers 147.]

Kusuma, Ananda B. (2009). Lahirnya Undang-Undang Dasar 1945: Memuat salinan dokumen otentik. Depok: Badan Penerbit Fakultas Hukum Universitas Indonesia.

Larbi, George A. (1999). The new public management approach and crisis states. Geneva: United Nations Research Institute for Social Development.

Lewin, Arie Y. (1982). 'Public enterprise, purposes and performance: A survey of Western European experience', in:W.T. Stanbury and F. Thompson (eds), Managing public enterprises, pp. 51-78. New York: Prager.

Liddle, R. William (1985). 'Soeharto's Indonesia: Personal rule and political institutions', Pacific Affairs: An International Review of the Far East and Pacific Area 58-1:68-9o.

Lindblad, J. Thomas (2006). 'Macroeconomic consequences of decolonization in Indonesia'. Paper presented at the xIvth conference of the International Economic History Association, Helsinki, 21-25 August. http://www.helsinki.fi/iehc2oo6/pape rs1/Lindblad.pdf (accessed 28-10-2019).

Lindblad, J. Thomas (2010). 'Economic growth and decolonisation in Indonesia', Itinerario 34-1:97-112. https://doi.org/10.1017/So165115310000070 (accessed 28-10-2019).

Lindblad, J. Thomas (2011). 'The economic decolonisation of Indonesia: A bird's- 
eye view', Journal of Indonesian Social Sciences and Humanities (JISSH) Vol. 4: 1-20. http://www.kitlv.nl/documents/library/TS/JISSH/35206683o.pdf (accessed 10-10-2018).

Lubis, Todung Mulya and Richard M. Buxbaum (1986). Peranan hukum dalam perekonomian di negara berkembang. Jakarta: Obor Indonesia.

Lucas, Anton and Carol Warren (2003). 'The state, the people, and their mediators: The struggle over agrarian law reform in post-New Order Indonesia', Indonesia 76:87-126. https://hdl.handle.net/1813/54302 (accessed 28-10-2019).

Ministry of Strategy and Finance Republic of Korea, Korean Development Institute, Samjong KPMG, Korean Credit Guarantee Fund (2016). 2014/15 knowledge sharing programme with Indonesia: Reforming economic institutions and state bureaucracy for a stronger Indonesia. Seoul: Ministry of Strategy and Finance, Republic of Korea.

Moeljono, Djokosantoso (2004). Reinvensi BUMN. Empat strategi membangun BUMN kelas dunia. Jakarta: Pт Elex Media Komputindo, Gramedia.

Musacchio, Aldo and Francisco Flores-Macias (2009). 'The return of state-owned enterprises: Should we be afraid?', Harvard International Review (4 April). http:// hir.harvard.edu/2009/o4/the-return-of-state-owned-enterprises/ (accessed 23-10 -2019).

Ngo, Jenny and Lynn Meek (2019). 'Higher education governance and reforms in Indonesia: Are the matrices of autonomy appropriate?', Journal of International and Comparative Education 8-1:17-26. https://doi.org/10.14425/jice.2019.8.1.17 (accessed 7-10-2019).

Nugraha, Safri (2004). Privatisation of state enterprises in the 2oth century: A step forwards or backwards? Jakarta: Institute for Law and Economics Studies, Faculty of Law, University of Indonesia.

Petersen, Ole, Ulf Hjelmar Helby, and Karsten Vrangbaek (2018). 'Is contracting out of public services still the great panacea? A systematic review of studies on economic and quality effects from 2000 to 2014', Social Policy \& Administration 52-1:130-57. https://doi.org/10.1111/spol.12297 (accessed 23-10-2019).

Pisani, Elizabeth, Maarten Olivier Kok, and Kharisma Nugroho (2017). 'Indonesia's road to universal health coverage: A political journey', Health Policy and Planning $3^{2-}$ 2:267-76. http://repub.eur.nl/pub/10o135 (accessed 23-10-2019).

Potrafke, Niklas (2010). 'Does government ideology influence deregulation of product markets? Empirical evidence from OECD countries', Public Choice 143-1/2:135-55. http://www.jstor.org/stable/406610o8 (accessed 23-1-2019).

Robison, Richard (1981). 'Culture, politics, and economy in the political history of the New Order', Indonesia 31:1-29. DoI:10.2307/3351013 (accessed 23-10-2019).

Robison, Richard (1988). 'Authoritarian states, capital-owning classes, and the politics of newly industrializing countries: The case of Indonesia', World Politics 41-1:52-74. DOI: 10.2307/2010479 (accessed 23-10-2019). 
Rock, Michael T. (2003). 'The politics of development policy and development policy reform in New Order Indonesia', William Davidson Institute Working Paper Series 632:1-47. http://deepblue.lib.umich.edu/bitstream/2027.42/40018/3/wp632.pdf (accessed 23-10-2019).

Rokx, Claudia, George Schieber, Ajay Tandon, Pandu Harimurti, and Aparnaa Somanathan (2009). Health financing in Indonesia: A reform road map. Directions in development; human development. Washington, DC: World Bank. https://openknowledge .worldbank.org/handle/10986/2710 (accessed 23-10-2019).

Rosser, Andrew (2018). Beyond access: Making Indonesia's education system work. Sydney: Lowy Institute. https://www.lowyinstitute.org/publications/beyond-access-ma king-indonesia-s-education-system-work (accessed 7-2-2020). [Analyses].

Saltford, John (2003). The United Nations and the Indonesian takeover of West Papua, 1962-1969: The anatomy of betrayal. London: Routledge Curzon.

Schick, Allen (1998). 'Why most developing countries should not try New Zealand's reforms', The World Bank Research Observer 13-1:123-31. https://elibrary.worldbank .org/doi/10.1093/wbro/13.1.123 (accessed 23-10-2019).

Sjöholm, Fredrik (1999). 'Economic recovery in Indonesia: The challenge of combining FDI and regional development'. Stockholm School of Economics Working Paper 84.

Sungkar, Yasmin (2008). 'Indonesia's state enterprises: From state leadership to international consensus', Journal of Indonesian Social Sciences and Humanities 1:95-120.

Susanti, Dewi (2011). 'Privatisation and marketisation of higher education in Indonesia: The challenge for equal access and academic values', Higher Education 61:209-18. https://doi.org/10.1007/s10734-010-9333-7 (accessed 7-2-2020).

The Indonesian Health System Group (2019). 'Universal health coverage in Indonesia: Concept, progress, and challenges', The Lancet, Jan 5, 393-10166:75-102.

Waluyo, Budi (2018). 'Balancing financial autonomy and control in agencification: Issues emerging from the Indonesian higher education', International Journal of Public Sector Management 31:794-810.

Warburton, Eve (2016). 'Jokowi and the New Developmentalism', Bulletin of Indonesian Economic Studies 52-3:297-320.

World Bank (2013). Indonesia-Spending more or spending better: Improving education financing in Indonesia. Jakarta: World bank Office for the East Asia and Pacific Region. http://documents.worldbank.org/curated/en/991011468254684449/Indone sia-Spending-more-or-spending-better-improving-education-financing-in-Indones ia (accessed 24-10-2019). [Report No. 73050].

World Bank (2015). Indonesia-Managing higher education for relevance and efficiency project. Washington, DC: World Bank Group. http://documents.worldbank.org/cur ated/en/185401468188648046/Indonesia-Managing-Higher-Education-for-Relevan ce-and-Efficiency-Project (accessed 24-10-2019). [Report No. 97132]. 